\section{Pacific Northwest}

National Laboratory

Operated by Battelle for the

U.S. Department of Energy

\title{
Electrical Power Interruption Cost Estimates for Individual Industries, Sectors, and U.S. Economy
}

\author{
P. J. Balducci \\ J. M. Roop \\ L. A. Schienbein \\ J. G. DeSteese \\ M. R. Weimar
}

February 2002

Prepared for the

U.S. Department of Energy

Office of Power Technologies

Office of Distributed Resources

under Contract DE-AC06-76RL01830

Prepared for the U.S. Department of Energy

under Contract DE-AC06-76RL01830 


\title{
DISCLAIMER
}

This report was prepared as an account of work sponsored by an agency of the United States Government. Neither the United States Government nor any agency thereof, nor Battelle Memorial Institute, nor any of their employees, makes any warranty, express or implied, or assumes any legal liability or responsibility for the accuracy, completeness, or usefulness of any information, apparatus, product, or process disclosed, or represents that its use would not infringe privately owned rights. Reference herein to any specific commercial product, process, or service by trade name, trademark, manufacturer, or otherwise does not necessarily constitute or imply its endorsement, recommendation, or favoring by the United States Government or any agency thereof, or Battelle Memorial Institute. The views and opinions of authors expressed herein do not necessarily state or reflect those of the United States Government or any agency thereof.

\author{
PACIFIC NORTHWEST NATIONAL LABORATORY \\ operated by \\ BATTELLE \\ for the \\ UNITED STATES DEPARTMENT OF ENERGY \\ under Contract DE-AC06-76RL01830
}

Printed in the United States of America

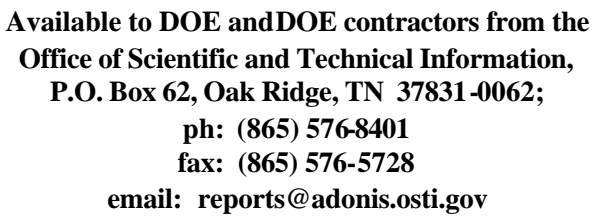

Available to the public from the National Technical Information Service, U.S. Department of Commerce, 5285 Port Royal Rd., Springfield, VA 22161 ph: (800) 553-6847 fax: $(703) 605-6900$

email: orders@ntis.fedworld.gov online ordering: http://www.ntis.gov/ordering.htm 


\title{
Electrical Power Interruption Cost Estimates for Individual Industries, Sectors, and U.S. Economy
}

\author{
P. J. Balducci \\ J. M. Roop \\ L. A. Schienbein \\ J. G. DeSteese \\ M. R. Weimar
}

February 2002

Prepared for the

U.S. Department of Energy

Office of Power Technologies

Office of Distributed Resources

under Contract DE-AC06-76RL01830

Pacific Northwest National Laboratory

Richland, Washington 99352 



\section{Summary}

Electrical power systems play a central and key role in the production of goods and services in both the commercial and industrial sectors, and directly and significantly affect the lives of private citizens. The U.S. bulk power grid has an average availability of about 99.96 percent. Although 99.96 percent represents a very high reliability (about 3.5 hours of downtime per year), even a moment's disruption can have devastating effects on power sensitive customers such as internet service providers, data centers, wireless telecommunication networks, on-line traders, computer chip manufacturers and medical research centers. For these customers, power disruptions can result in data corruption, burned circuit boards, component damage, file corruption and lost customers.

While distributed energy resources (DER) are being heavily promoted as the least-cost approach to meeting steadily increasing demand, a critical question remains: Can DER deployment also maintain or improve the electric power supply reliability and power quality currently available to consumers? This report addresses two key factors that must be analyzed and understood to help answer this question: 1) characteristics of existing power supply reliability, and 2) costs resulting from supply interruptions (or outages) characteristic of the power grid, as it exists today. These costs, incurred mostly by power consumers, and their distribution amongst the various industrial, commercial, transportation and residential sectors, must be completely understood because they are a principal driver for the commercial deployment of DER systems already taking place.

This report focuses on one element within the analysis of the benefits and costs associated with improved system reliability - interruption costs. These costs can take both direct and indirect forms. Direct costs include lost production, idle facilities and labor, damage to electronic data, damaged or spoiled product, damage to equipment or customer refunds. Residential customers may experience direct out-of-pocket expense (e.g., the purchase of wood for home heating, alternative light sources, food spoilage or damage to electrical equipment) as a result of power interruption. In addition to direct costs, there are several types of indirect costs (e.g., accidental injuries, looting, vandalism, legal costs, loss of water supply, increases in insurance rates) with monetary impacts that, in some cases, may exceed direct costs.

Although limited by constraints in the data used, the analysis presented in this report indicate that an interruption in power supply can result in considerable costs to end-users in the industrial, commercial and transportation sectors. The findings of this and other studies of interruption costs conclude that outage costs vary significantly based on the demand characteristics of the end-user. Interruption costs appear to be highest in the transportation sector at $\$ 16.42 / \mathrm{kW}$ for a 1-hour interruption, followed by the industrial sector $(\$ 13.93 / \mathrm{kW})$ and the commercial sector $(\$ 12.87 / \mathrm{kW})$. Residential customers incur costs $(\$ 0.15 / \mathrm{kW}$ for a 1 -hour interruption) that are a fraction of those incurred by end-users in the other sectors.

While the costs associated with improved system reliability through investment in new facilities and equipment are well documented, the benefits that accrue to the U.S. economy as a result of improved system reliability are more difficult to quantify with precision. However, the findings of this and other cited studies indicate that the societal worth of electric power system reliability is significant.

During the last 20 years, utilities and researchers have begun to understand the value in the collection and analysis of interruption cost data. The continued investigation of the monetary impact of power outages will facilitate advancement of the analytical methods used to measure costs and benefits from the 
perspective of the energy consumer. More in-depth analysis may be warranted to consider the effects of privatization and deregulation of power utilities, price instability in certain regions of the U.S., and the continued evolution of alternative auxiliary power systems. Further research would be needed to address the costs associated with power quality events such as power surges, spikes, sags, line noise, frequency variation, switching transients and brownouts. 


\section{Contents}

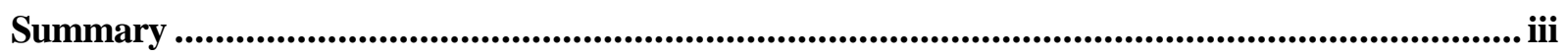

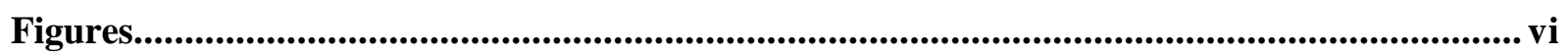

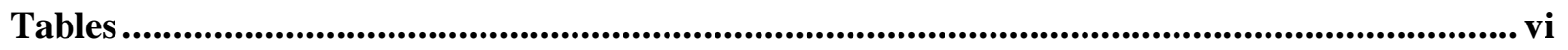

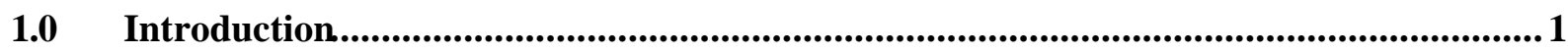

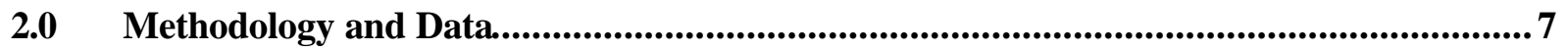

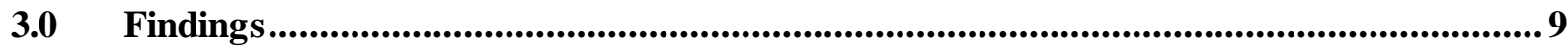

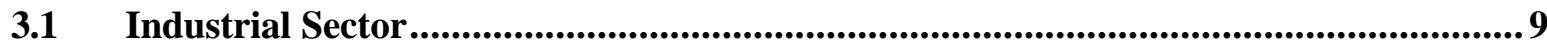

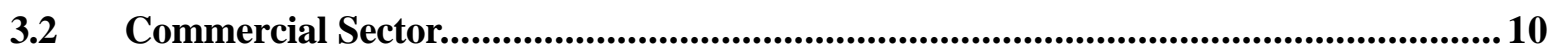

3.3 Transportation Sector.............................................................................. 11

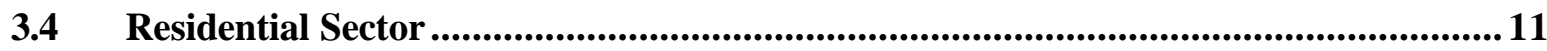

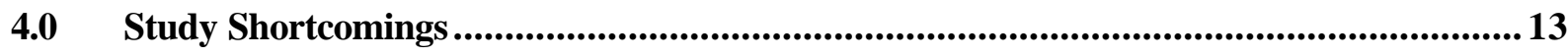

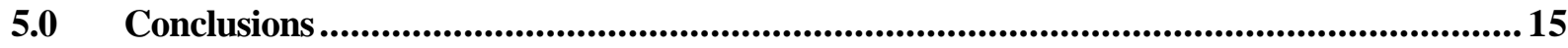

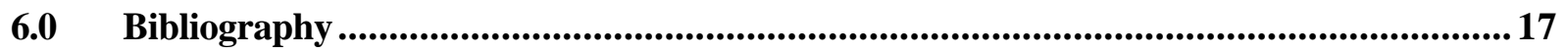

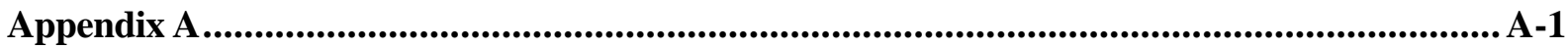




\section{Figures}

$\begin{array}{ll}\text { 1. Electricity Utility Retail Sales, 1970-2000 } & 1\end{array}$

\section{Tables}

1. Cost of the New York City Blackout - 1977

2. Summary of Interruption Cost Studies $\quad 5$

3. Interruption Cost in 1996 US\$/kW by Sector 9

4. Interruption Cost in 1996 US\$/kW for the Industrial Sector 10

5. Interruption Cost for Sensitive Electricity Consumers in the Commercial Sector $\quad 11$

6. Interruption Cost in 1996 US\$/kW for the Commercial Sector 11 


\subsection{Introduction}

This report is an account of work conducted by Pacific Northwest National Laboratory (PNNL) for the U.S. Department of Energy (DOE) Office of Power Technologies (OPT) as part of a project to assess the power quality and power reliability implications of distributed energy resources (DER). This task report focuses on one element, interruption costs, within the analysis of the benefits and costs associated with improved systems reliability.

Electrical power systems play a central and key role in the production of goods and services in both the commercial and industrial sectors, and directly and significantly affect the lives of private citizens. In this era of increasing demand for energy (Figure 1), growing competition within the electric utility industry, and volatile electricity prices, it has become evident that continued growth of the U.S. economy could depend, in large part, on the reliability and sustainability of the nation's energy supply system.

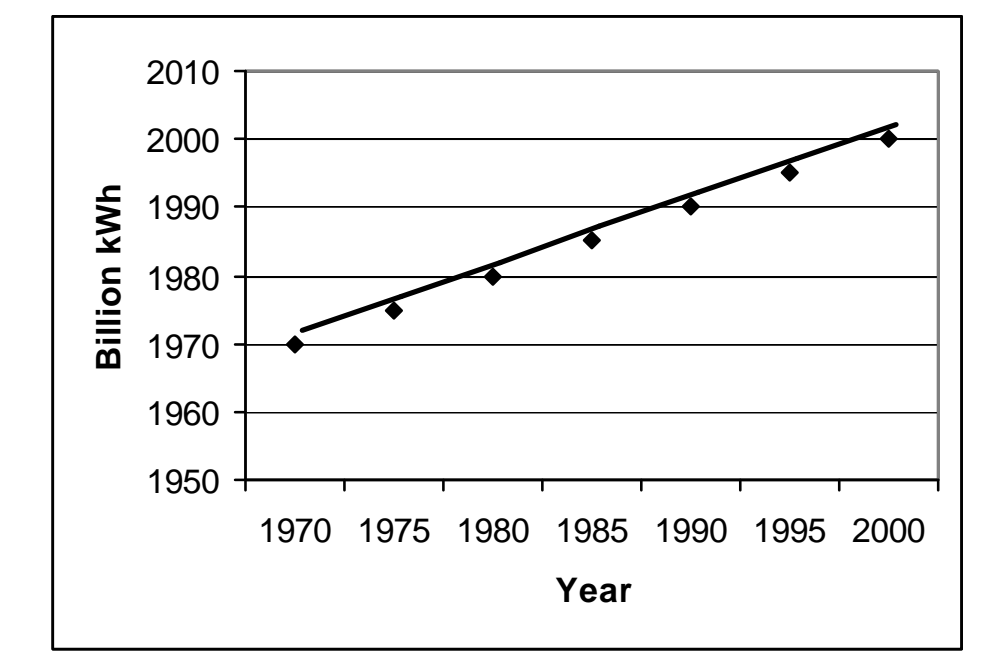

Source: U.S. Energy Information Administration, 2000 Annual Energy Review

Figure 1. Electricity Utility Retail Sales, 1970-2000

The demand for electricity is forecast to increase significantly during the next 20 years. Domestic demand for electricity is expected to increase by more than 1 trillion kilowatt-hours by 2020. During the same time frame, growth in demand for electricity outside the United States is forecast to increase by almost 9 trillion kilowatt-hours (1999). Growing demand for electricity could strain the capacity of the existing electrical power grid.

Distributed energy resources operating both as part of the grid and in the off-grid mode may offer a means to meet the demand growth, while maintaining and even improving grid reliability and power quality. 
While DER is being heavily promoted as the least cost approach to meeting the steadily increasing demand, a critical question remains. That is, can DER deployment also maintain the electric power supply reliability and power quality currently available to the customers? This report addresses two key factor that must be analyzed and understood to help answer this question - the characteristics of existing power supply reliability and the costs resulting from the supply interruptions (or outages) characteristic of the power grid, as it exists today. These costs, incurred mostly by the power customers, and their distribution among the various industrial, commercial, transportation and residential sectors must be completely understood. They are principal drivers for the commercial deployment of DER systems already taking place (e.g., uninterruptible power supplies (UPS)) and a major factor in determining the nature and form (i.e., architecture) of DER deployment and operation in the future electrical power grid system.

The U.S. bulk power grid operates appliances, lights and electric motors at an availability of about 99.96 percent. This is generally referred to as approaching " 4 nines" of reliability. In terms of power outages, "4 nines" of reliability corresponds to approximately 1 hour of downtime per year. Although 99.96 percent represents a very high reliability (about 3.5 hours of downtime per year), even a moment's disruption can have devastating effects on power sensitive customers such as internet service providers, data centers, wireless telecommunication networks, on-line traders, computer chip manufacturers and medical research centers. For these customers, power disruptions can result in data corruption, burned circuit boards, component damage, file corruption and lost customers.

New high-tech firms operating in the digital economy require premium power with limited interruption. However, the cost of adding "nines" to the rate of reliability is exponential rather than linear. For example, utilities sell electricity with at least " 3 nines" of reliability at a retail price of $\$ 0.06$ to $\$ 0.12 / \mathrm{kWh}$, with prices varying based on geographic location and other factors. To achieve " 6 nines" of reliability (downtime reduced from 8.75 hours to 30 seconds annually), a consumer might use a fuel cell, UPS, diesel generator or flywheel to generate a nearly uninterrupted supply of electricity. The cost of these additional approximately 8.74 hours of power supply integrity can be as much as $\$ 1,000$ per $\mathrm{kWh}$ delivered (Stephens, Inc., 2000). Nevertheless, power sensitive consumers with millions to lose in the event of a power outage often view an expenditure on UPS systems as a prudent investment.

The costs associated with improved system reliability through investment in new facilities and equipment are well documented. The benefits that accrue to the U.S. economy as a result of improved system reliability, however, are much more difficult to quantify and assign to individual industries or customers. Thus, power system planners and industrial and commercial customers are now faced with the difficult task of finding the optimum balance between the costs associated with investment in energy infrastructure and the benefits realized through improved system reliability.

Further research would be needed to address the costs associated with sub-optimal power quality events such as power surges, spikes, sags, line noise, frequency variation, switching transients or brownouts. While it is not technically nor economically feasible to produce a 100-percent reliable electrical energy supply system, it is important to note that an interruption in power supply can result in enormous costs to 
industrial and commercial users. These costs can take both direct and indirect forms. Direct costs include lost production, idle facilities and labor, damage to electronic data, damaged or spoiled product, damage to equipment or customer refunds. Residentialcustomers may experience direct out-of-pocket expense (e.g., the purchase of wood for home heating, alternative light sources, food spoilage or damage to electrical equipment) as a result of power interruption. In addition to direct costs, there are several types of indirect costs (e.g., accidental injuries, looting, vandalism, legal costs, loss of water supply, increases in insurance rates) with monetary impacts that, in some cases, may exceed direct costs. In fact, an analysis of the interruption costs incurred as a result of the 1977 New York City blackout estimated that the indirect costs of the blackout exceeded direct costs by a margin of 5 to 1 (Table 1).

To date, studies of power outages have produced wide-ranging estimates of end-user interruption costs. Alhough the estimates have not always been consistent, one fact is clearly supported by virtually all the data presented in this and other studies - outage costs vary significantly based on the demand characteristics of the end-user.

Numerous studies have attempted to estimate the costs associated with power interruptions. Table 2 provides summary information for several interruption cost studies. In Table 2, studies are listed with the geographic area studied, year of publication and findings. Billinton used survey data collected in Saskatchewan, Canada in 1982, 1992 and 1996 to produce interruption cost estimates for the industrial, commercial and residential sectors. Billinton found that interruption costs for the industrial sector grew slightly between 1982 and 1996, while the costs for the commercial sector grew sharply during the same time period. There have been a small group of studies conducted in North America, yielding a wide range of interruption cost estimates - from US $\$ 0.60 / \mathrm{kWh}$ to Canadian (C) $\$ 91 / \mathrm{kW}$ for a 1-hour interruption. Generally, residential customers experience the lowest interruption costs, while commercial customers experience the highest costs, even after normalizing the data.

In 1995, a study conducted by the Electric Power Research Institute (EPRI) found that power outages and other power quality disturbances cost the U.S. economy approximately $\$ 30$ billion annually. In 2001, EPRI revised their estimate upward to $\$ 119$ billion annually, representing an increase of almost 300 percent over the previous estimate. Note that the EPRI studies include both power outage and power quality disturbance costs, whereas all the other studies referenced in Table 2 identify only interruption costs.

This report is divided into five sections with the first being this introduction. The second section provides an overview of the study methodology and data. The third section presents study findings. The fourth section analyzes study shortcomings. The fifth, and final, section presents study conclusions. All interruption cost estimates prepared for this report are presented in terms of 1996 US\$. 
Table 1. Cost of the New York City Blackout - 1977

\begin{tabular}{|c|c|c|c|c|}
\hline Impact Areas & \multicolumn{2}{|c|}{ Direct Costs (\$M) } & \multicolumn{2}{|c|}{ Indirect Costs (\$M) } \\
\hline Businesses & $\begin{array}{l}\text { Food Spoilage } \\
\text { Wages Lost } \\
\text { Securities Industry } \\
\text { Banking Industry }\end{array}$ & $\begin{array}{r}1.0 \\
5.0 \\
15.0 \\
13.0\end{array}$ & $\begin{array}{l}\text { Small Businesses } \\
\text { Private Emergency Aid }\end{array}$ & $\begin{array}{r}155.4 \\
5.0\end{array}$ \\
\hline Government & & & $\begin{array}{l}\text { Federal Assistance } \\
\text { Programs } \\
\text { New York Assistance } \\
\text { Programs }\end{array}$ & $\begin{array}{r}11.5 \\
1.0\end{array}$ \\
\hline $\begin{array}{l}\text { Consolidated } \\
\text { Edison }\end{array}$ & $\begin{array}{l}\text { Restoration Costs } \\
\text { Overtime Payments }\end{array}$ & $\begin{array}{r}10.0 \\
2.0\end{array}$ & New Capital Equipment & 65.0 \\
\hline Insurance & & & $\begin{array}{l}\text { Federal Crime Insurance } \\
\text { Fire Insurance } \\
\text { Private Property Insurance }\end{array}$ & $\begin{array}{r}3.5 \\
19.5 \\
10.5\end{array}$ \\
\hline $\begin{array}{l}\text { Public Health } \\
\text { Services }\end{array}$ & & & $\begin{array}{l}\text { Public Hospitals- Overtime, } \\
\text { Emergency Room Charges }\end{array}$ & 1.5 \\
\hline $\begin{array}{l}\text { Other Public } \\
\text { Service }\end{array}$ & $\begin{array}{l}\text { Metropolitan } \\
\text { Transportation } \\
\text { Authority (MTA): } \\
\text { Revenue Losses } \\
\text { Overtime and Labor }\end{array}$ & $\begin{array}{l}2.6 \\
6.5\end{array}$ & $\begin{array}{l}\text { MTA Vandalism } \\
\text { MTA Capital Equipment } \\
\text { Red Cross } \\
\text { Fire Department } \\
\text { Police Department } \\
\text { State Courts } \\
\text { Prosecution and Correction }\end{array}$ & $\begin{array}{c}0.2 \\
11.0 \\
0.01 \\
0.5 \\
4.4 \\
0.5 \\
1.1\end{array}$ \\
\hline $\begin{array}{l}\text { Westchester } \\
\text { County }\end{array}$ & $\begin{array}{l}\text { Food Spoilage } \\
\text { Public Services: } \\
\text { Equipment Damage } \\
\text { Overtime Payments }\end{array}$ & $\begin{array}{l}0.25 \\
0.19\end{array}$ & & \\
\hline Total & & $\$ 55.54$ & & $\$ 290.16$ \\
\hline
\end{tabular}


Table 2. Summary of Interruption Cost Studies

\begin{tabular}{|c|c|c|c|}
\hline $\begin{array}{c}\text { Author } \\
\text { (Reference) }\end{array}$ & $\begin{array}{l}\text { Geographic } \\
\text { Area }\end{array}$ & $\begin{array}{l}\text { Data } \\
\text { Series } \\
\text { Date }\end{array}$ & Finding \\
\hline $\begin{array}{l}\text { Billinton and Wacker } \\
\text { (Billinton 2001) }\end{array}$ & Canada & 1982 & $\begin{array}{l}\text { Industrial - C } \$ 5.19 / \mathrm{kW} \text { - 1-hr Interruption } \\
\text { Commercial - C } \$ 5.88 / \mathrm{kW} \text { - 1-hr Interruption } \\
\text { Residential - C } \$ 0.31 / \mathrm{kW} \text { - 1-hr Interruption }\end{array}$ \\
\hline $\begin{array}{l}\text { Billinton and Wacker } \\
\text { (Billinton 2001) }\end{array}$ & Canada & $\begin{array}{l}1992, \\
1996\end{array}$ & $\begin{array}{l}\text { Industrial - C\$9.56/kW - 1-hr Interruption } \\
\text { Commercial - C } \$ 32.20 / \mathrm{kW} \text { - 1-hr Interruption } \\
\text { Residential - C } \$ 0.16 / \mathrm{kW} \text { - 1-hr Interruption }\end{array}$ \\
\hline $\begin{array}{l}\text { Billinton and Pandey } \\
\text { (Billinton 2001) }\end{array}$ & Nepal & 1996 & Residential - US $\$ 0.19$ - 1-hr Interruption \\
\hline $\begin{array}{l}\text { Dali, Dialynas and } \\
\text { Megaloconomous }\end{array}$ & Greece & 2001 & $\begin{array}{l}\text { Mining - US } \$ 2.49 / \mathrm{kW}-1 \text {-hr Interruption } \\
\text { Metal Fabrication - US } \$ 7.36 / \mathrm{kW} \text { - 1-hr Interruption } \\
\text { Food Ind. - US } \$ 20.5 / \mathrm{kW} \text { - 1-hr Interruption }\end{array}$ \\
\hline EPRI (EPRI 2001) & U.S. & 1995 & Entire U.S. Economy - US\$30 Billion Annually \\
\hline EPRI (EPRI 2001) & U.S. & 2001 & Entire U.S. Economy - US\$119 Billion Annually \\
\hline Gannon & U.S. & 1976 & $\begin{array}{l}\text { Industrial - US } \$ 2.68 / \mathrm{kWh} \\
\text { Commercial - US } \$ 7.21 / \mathrm{kWh}\end{array}$ \\
\hline Jenkins, Lim and Shukla & Mexico & 1999 & $\begin{array}{l}\text { Industrial - US } \$ 1.2 / \mathrm{kWh} \\
\text { Commercial - US } \$ 0.75 / \mathrm{kWh} \\
\text { Residential - US } \$ 0.70 / \mathrm{kWh}\end{array}$ \\
\hline $\begin{array}{l}\text { Lehtonen and } \\
\text { Lemstroem } \\
\text { (Lehtonen et al. 1995) }\end{array}$ & Denmark & $\begin{array}{l}1992- \\
1993\end{array}$ & $\begin{array}{l}\text { Industrial - US } \$ 24.06 / \mathrm{kW} \text { - 1-hr Interruption } \\
\text { Commercial - US } \$ 9.25 / \mathrm{kW} \text { - 1-hr Interruption } \\
\text { Residential - US } \$ 7.19 / \mathrm{kW} \text { - 1-hr Interruption }\end{array}$ \\
\hline $\begin{array}{l}\text { Lehtonen and } \\
\text { Lemstroem } \\
\text { (Lehtonen et al. 1995) }\end{array}$ & Finland & $\begin{array}{l}1992- \\
1993\end{array}$ & $\begin{array}{l}\text { Industrial - US } \$ 15.79 / \mathrm{kW} \text { - 1-hr Interruption } \\
\text { Commercial - US } \$ 17.86 / \mathrm{kW} \text { - 1-hr Interruption } \\
\text { Residential - US } \$ 3.16 / \mathrm{kW} \text { - 1-hr Interruption }\end{array}$ \\
\hline $\begin{array}{l}\text { Lehtonen and } \\
\text { Lemstroem } \\
\text { (Lehtonen et al. 1995) }\end{array}$ & Iceland & $\begin{array}{l}1992- \\
1993\end{array}$ & $\begin{array}{l}\text { Industrial - US } \$ 13.61 / \mathrm{kW} \text { - 1-hr Interruption } \\
\text { Commercial - US } \$ 22.86 / \mathrm{kW} \text { - 1-hr Interruption } \\
\text { Residential - US } \$ 3.48 / \mathrm{kW} \text { - 1-hr Interruption }\end{array}$ \\
\hline $\begin{array}{l}\text { New York City Office of } \\
\text { Economic D evelopment } \\
\text { (NYEDA) }\end{array}$ & $\begin{array}{l}\text { New York } \\
\text { State }\end{array}$ & 1971 & US\$2.5 Million/Hr \\
\hline Ontario Hydro & Canada & 1977 & $\begin{array}{l}\text { C\$15/kW - 15-min. Interruption } \\
\mathrm{C} \$ 91 / \mathrm{kW} \text { - 1-hr Interruption }\end{array}$ \\
\hline Shipley & U.S. & 1972 & US\$0.60/kWh \\
\hline Stoll & U.S. & 1989 & Industrial/Commercial - US $\$ 7 / \mathrm{kWh}$ \\
\hline Train and Woo & $\begin{array}{l}\text { PG\&E Service } \\
\text { Area }\end{array}$ & 1983 & US\$6.72/kWh \\
\hline Willis and Scott & United States & 2000 & $\begin{array}{l}\text { Agriculture - US } \$ 0.43-U S \$ 0.86 / \mathrm{kWh} \\
\text { Residential - US } \$ 0.51-U S \$ 1.04 / \mathrm{kWh} \\
\text { Retail Commercial - US } \$ 3.11-\mathrm{US} \$ 5.11 / \mathrm{kWh} \\
\text { Other Commercial - US } \$ 3.88-\mathrm{US} \$ 5.95 / \mathrm{kWh} \\
\text { Industrial - US } \$ 0.86-\mathrm{US} \$ 1.59 / \mathrm{kWh} \\
\text { Municipal - US } \$ 1.89-\mathrm{US} \$ 5.02 / \mathrm{kWh}\end{array}$ \\
\hline
\end{tabular}




\subsection{Methodology and Data}

When analyzing interruption costs, the goal is to identify outage costs incurred by end-users of electricity within a wide range of industries for varying durations of time. Unfortunately, the analysis of interruption costs is difficult as a result of the lack of available data and the imprecision evident in most data sets. To overcome the data barrier, several methods have been developed to identify interruption costs by industry. The three most common methods are:

1. Customer Survey: This method uses surveys of industrial, commercial and residential sector customers to determine the cost of an interruption from the perspective of the individual customer. Surveys generally request interruption cost estimates for varying durations of time (e.g., 10 minutes, 30 minutes, 1 hour, 4 hours). The customer surveys are designed to obtain a statistically significant sample from several different industries. By aggregating and normalizing the data, the surveyor is then able to establish interruption cost estimates by industry and sector. When properly designed and executed, this approach can generate reliable cost estimates based on data provided directly by endusers. The primary problem with this method is the time and high cost associated with survey design and distribution, as well as the collection and analysis of respondent data.

2. Blackout Case Study: The basis of this method is the after-the-fact analysis of specific interruptions. This approach has been limited to blackouts of large metropolitan population centers such as New York City. The 1977 New York City blackout has been studied more extensively than any other outage. The blackout case study method provides more detailed and direct cost estimates that include indirect costs not adequately captured in other forms of analysis. However, the study findings are limited as a result of geographic constraints and the characteristics and duration of the specific outage being studied.

3. Ratio of Gross Economic Output to Energy Consumption: This method uses the ratio of a gross economic measure (e.g., gross output, gross domestic product [GDP]) and a measure of electricity consumption (e.g., peak $\mathrm{kW}$ load or $\mathrm{kWh}$ ) to estimate interruption costs by industry. Based on this method, if an industry consumes 100 million $\mathrm{kWh}$ of electricity to produce $\$ 1$ billion in output, each $\mathrm{kWh}$ of electricity is tied to $\$ 10$ in productivity. Thus, the cost of an outage would be estimated as $\$ 10 / \mathrm{kWh}$ in lost productivity. This method uses readily available data to perform a straightforward analysis for any industry for which electricity consumption data exist. The disadvantage of this approach is that it is based on severely limiting assumptions that are often invalid, it does not capture many direct costs, and it ignores virtually all indirect costs.

Despite inherent limitations, this study uses survey data collected from Canadian energy consumers by the University of Saskatchewan in 1992 and 1996. The 1992 survey captured data from the residential, industrial and a majority of the industries in the commercial sector. The 1996 survey obtained data from the government, banking, insurance, real estate, health and other service industries.

The University of Saskatchewan data were used to establish interruption cost functions for individual customers. The interruption cost incurred by a consumer of electricity is presented as a function of outage 
duration (e.g., 20 minutes, 1 hour and 4 hours). The interruption cost estimate represented as a function of outage duration is a customer damage function (CDF).

Cost parameters must be established to normalize interruption cost data and aggregate data into standard industrial classific ation (SIC) group customer damage functions (GCDF). The most common cost parameters are: the cost of the interruption divided by the annual peak load or maximum demand in $\mathrm{kW}$ $(\$ / \mathrm{kW})$, the dollar cost of the interruption in terms of unsupplied energy in $\mathrm{kWh}(\$ / \mathrm{kWh})$ and cost per interruption (\$/interruption).

The University of Saskatchewan data were normalized using the $\$ / \mathrm{kW}$ parameter. To illustrate how this parameter works, consider the following case study. A pipe-rolling factory suffers a 1-hour power interruption. As a result of the 1-hour interruption, materials used in the manufacturing process must be cleared from the rolling, welding and polishing machinery. The machines that process the raw materials must be reset so that the process can restart once the power resumes. Additional costs are incurred as the result of lost production and idle labor. In this case, the 1-hour interruption costs the owner of the piperolling factory $\$ 46,000$ as a result of lost productivity and labor costs. Assuming that the annual peak load for the pipe-rolling factory is $10,000 \mathrm{~kW}$, the normalized cost of the 1-hour interruption would be $\$ 4.60 / \mathrm{kW}$.

The University of Saskatchewan study established GCDFs for groups of customers based on Canadian SIC codes. For this analysis, the Canadian GCDFs were placed into corresponding U.S. SIC groups. The University of Saskatchewan survey reached most manufacturing, agriculture, government, mining and retail SIC groups. Data from transportation, service and construction SIC groups, however, are generally missing or incomplete. To fill data gaps, peer groups were established based on business operations and demand characteristics. Representative industry data were then used as a proxy for interruption costs within groups with missing data.

Cost estimates presented in the University of Saskatchewan study were presented in terms of Canadian dollars. The cost estimates produced in 1992 were converted to U.S. dollars based on 1992 CanadianU.S. exchange rates. The 1996 data were converted to U.S. dollars based on 1996 exchange rates. Further, data presented in terms of 1992 dollars were inflated to 1996 dollars based on the GDP Implicit Price Deflator.

The interruption cost estimates for all SIC groups were used to construct industry customer damage functions (ICDFs). ICDFs were generated for the agriculture, mining, construction, manufacturing, transportation, commercial, utilities, wholesale, retail and services industries, along with residential and government consumers. Three weighting factors were used to construct ICDFs - relative share of total industry-wide electricity consumption, relative share of industry GDP and relative share of gross output. ICDFs were then used to generate sector customer damage functions (SCDFs) for the industrial and commercial sectors based on relative shares of GDP. No additional weighting was required to produce SCDFs for the transportation and residential sectors. Finally, SCDFs for the industrial, commercial, transportation and residential sectors were weighted based on relative shares of electricity consumption to produce an interruption cost estimate for the entire U.S. economy. 


\subsection{Findings}

Table 3 presents SCDFs for the industrial, commercial, transportation, and residential sectors. Weighted average interruption costs for the entire U.S. economy are also presented. SCDFs are presented in terms of cost per peak load or maximum demand in $\$ / \mathrm{kW}$ and the interruption duration in hours. SCDFs for a 1-hour interruption range from a low of $\$ 0.15 / \mathrm{kW}$ in the residential sector to a high of $\$ 16.42 / \mathrm{kW}$ in the transportation sector. The weighted average cost of a 1-hour interruption for all sectors is $\$ 8.76 / \mathrm{kW}$. The SCDF for the industrial sector is relatively high during a short outage, but comparatively low for longer outage durations. The SCDF for the residential sector is a fraction of the SCDFs for all other sectors. Note that interruption costs increase with duration in a non-linear manner.

Table 3. Interruption Cost in 1996 US\$/kW by Sector

\begin{tabular}{|l|r|r|r|}
\hline \multirow{2}{*}{\multicolumn{1}{|c|}{ Sector }} & \multicolumn{3}{|c|}{ Duration of Interruption } \\
\cline { 2 - 4 } & 20 Minutes & 1.0 Hour & 4.0 Hours \\
\hline Industrial & 6.29 & 13.93 & 29.94 \\
\hline Commercial & 4.74 & 12.87 & 44.37 \\
\hline Residential & 0.03 & 0.15 & 1.64 \\
\hline Transportation & 8.91 & 16.42 & 45.95 \\
\hline Weighted Average & 3.59 & 8.76 & 24.90 \\
\hline
\end{tabular}

\subsection{Industrial Sector}

Industrial operations are highly sensitive to power disruptions. A momentary outage can shut down manufacturing operations for several minutes or hours. Industrial sector customers experience lost production, idle facilities and labor, damage and spoiled product and damaged equipment in the event of a sustained power outage. One case study of a plastic sheet manufacturing plant found that any power outage costs the plant a minimum of $\$ 38,000$ in lost productivity and labor costs resulting from production set-up time. Further, the case study found that costs rose slowly for 30 minutes until molten feed stock and other ingredients in pipes and pumps began to cool and harden. Hardened ingredients resulted in a day-long cleaning and equipment maintenance operation that created enormous costs to the manufacturer.

To construct an SCDF for the industrial sector, interruption cost data for 32 SIC groups were aggregated and weighted based on relative shares of sector GDP. The industrial sector SCDF for a 20-minute interruption is $\$ 6.29 / \mathrm{kW}$, a 1-hour outage equates to a cost of $\$ 13.93 / \mathrm{kW}$ and a 4hour interruption costs industrial sector industries an average of $\$ 29.94 / \mathrm{kW}$.

The industrial sector is comprised of agriculture, mining, construction and manufacturing industries. Each ICDF shows how a power failure might affect a constituent industry. The monetary impact of an interruption on any industry varies significantly based on the demand characteristics of that industry. Table 4 presents GCDFs for several SIC groups in the industrial sector. As shown, interruption costs are extremely low for agriculture and coal mining operations. The GCDF for the oil and gas extraction industry, however, is extremely high, more than three times higher than any other industry included in the 
University of Saskatchewan study. Predictably, the GCDF for the food and kindred products industry yields high costs during sustained outages as a result of product spoilage. Individual GCDFs for each SIC group in the industrial sector are shown in Appendix A.

Table 4. Interruption Cost in 1996 US\$/kW for the Industrial Sector

\begin{tabular}{|l|r|r|r|}
\hline \multirow{2}{*}{ Industry } & \multicolumn{3}{|c|}{ Duration of Interruption } \\
\cline { 2 - 4 } & $\mathbf{2 0}$ Minutes & $\mathbf{1 . 0}$ Hour & 4.0 Hours \\
\hline Agriculture - crops & 0.02 & 0.12 & 1.28 \\
\hline Coal Mining & 1.34 & 2.11 & 4.66 \\
\hline Oil and Gas Extraction & 81.47 & 193.88 & 205.85 \\
\hline Food and Kindred Products & 4.74 & 15.10 & 50.52 \\
\hline Primary Metals Industry & 1.55 & 2.49 & 5.26 \\
\hline Industrial Machinery and Equipment & 3.02 & 5.40 & 18.45 \\
\hline Electrical and Electronic Equipment & 3.48 & 6.60 & 19.89 \\
\hline
\end{tabular}

\subsection{Commercial Sector}

The commercial sector incorporates a wide variety of service industries. Because of the growing reliance on technology and computers, most commercial operations are extremely sensitive to power disruptions. Even short outages to commercial operations have extremely high costs resulting from damage to electronic data and equipment jamming. Long disruptions can result in spoiled product, lost business and customer refunds.

A case study of an insurance claim office found that a momentary power interruption resulted in data losses equivalent to 1 hour's processing. During an interruption, agents are re-directed to other, less productive activities such as filing. The re-assignment of work and resumption of production generally takes approximately 30 minutes. Thus, each power outage results in a loss of 90 minutes of productivity.

Case studies of power sensitive electricity consumers suggest that interruption costs can exceed $\$ 1$ million per hour, as demonstrated in Table 5. Further, Sun Microsystems once estimated interruption costs at up to $\$ 1$ million per minute. With increased reliance on power-sensitive machines and computerbased systems, concerns about power reliability are growing in the U.S. Firms operating in the digital economy require premium, high quality power. In turn, the demand for high reliability has led to an increase in global sales of energy generation equipment, including distributed energy systems such as reciprocating engines, gas turbines, fuel cells wind turbines and photovoltaic cells.

The commercial sector is comprised of 35 SIC groups in the communications, utility, wholesale, retail and service industries. The commercial sector also includes government services. The SCDF for the commercial sector indicates that a 20 -minute interruption results in costs equivalent to $\$ 4.74 / \mathrm{kW}$, a 1 hour interruption in costs equal to $\$ 12.87 / \mathrm{kW}$ and a 4 hour interruption costs an average of $\$ 44.37 / \mathrm{kW}$. Compared to the industrial sector, interruption costs in the commercial sector are relatively low during short outages, but escalate rapidly during long outages. In fact, the commercial sector SCDF exceeds the industrial sector SCDF by nearly 50 percent during a 4hour interruption. 
Table 5. Interruption Cost for Selected Sensitive Electricity Consumers in the Commercial Sector

\begin{tabular}{|l|r|}
\hline \multicolumn{1}{|c|}{ Industry } & Average Cost (US\$/hr) \\
\hline Cellular Communications & 41,000 \\
\hline Telephone Ticket Sales & 72,000 \\
\hline Airline Reservations & 90,000 \\
\hline Credit Card Operations & $2,580,000$ \\
\hline Brokerage Operations & $6,480,000$ \\
\hline
\end{tabular}

Table 6 presents interruption cost estimates for several SIC groups in the commercial sector. GCDFs vary significantly based on the characteristics of each group. GCDFs for the educational and accommodations service industries are very low. Recreation and eating and drinking establishments, however, incur high costs for sustained outages, principally because of the customer's unwillingness to wait for the resumption of service and subsequent refund demands.

Table 6. Interruption Cost in 1996 US\$/kW for the Commercial Sector

\begin{tabular}{|l|r|r|r|}
\hline \multirow{2}{*}{\multicolumn{1}{|c|}{ Industry }} & \multicolumn{3}{c|}{ Duration of Interruption } \\
\cline { 2 - 4 } & $\mathbf{2 0}$ Minutes & $\mathbf{1 . 0}$ Hour & $\mathbf{4 . 0}$ Hours \\
\hline Eating and Drinking Places & 9.47 & 28.41 & 147.93 \\
\hline Depository Institutions & 1.93 & 5.67 & 17.50 \\
\hline $\begin{array}{l}\text { Insurance Agents, Brokers and } \\
\text { Service }\end{array}$ & 24.16 & 29.39 & 58.49 \\
\hline $\begin{array}{l}\text { Hotels, Rooming Houses, Camps and } \\
\text { Other Lodging }\end{array}$ & & & \\
\hline Amusement and Recreation Services & 0.41 & 1.13 & 3.05 \\
\hline Educational Services & & & 78.01 \\
\hline
\end{tabular}

\subsection{Transportation Sector}

Power interruptions affect all modes of transportation. Airlines, subways, trolleys and street traffic grind to a halt when power interruptions affect air traffic control centers, power supplies to rail cars and traffic lights. In the event of a blackout, tollbooths do not operate, parking lot gates experience failures and significant delays can be expected at airports, even though they continue to operate on auxiliary generators. Transportation sector interruption costs range from $\$ 8.91$ for a 20 -minute interruption to $\$ 45.95$ for a prolonged 4hour interruption.

\subsection{Reside ntial Sector}

Energy disruptions have a significant and direct affect on the lives of private citizens. In the absence of electricity, heating systems fail, lights are inoperable, electronic appliances do not operate and may be damaged, food may spoil, radios do not work and televisions remain dark. In essence, the lives of 
Americans are enormously disrupted during power outages. The resulting inconveniences, however, do not result in high costs. The residential sector experiences by far the lowest interruption costs of any sector, ranging from $\$ 0.03 / \mathrm{kW}$ for a 20 -minute interruption to $\$ 1.64 / \mathrm{kW}$ for a 4 -hour interruption. 


\subsection{Study Shortcomings}

There are numerous problems inherent in any study of power interruption costs. The data obtained from the University of Saskatchewan and analyses conducted for this study are not immune from data and methodological shortcomings. Thus, the confidence and accuracy of the findings presented in this report are limited as a result of constraints in the data set and lack of consistent data in the U.S. The following study shortcomings have been identified:

- Data Obtained from Canadian Study - The data set used in this study was obtained from a survey of Canadian firms conducted by the University of Saskatchewan. To the extent that the demand characteristics of, and relative costs incurred by, Canadian industrial and commercial consumers vary from those in the U.S., interruption cost estimates produced by the Canadian data will fail to yield comparable results for U.S. industries. Note that the findings of interruption cost studies produced in Canada have generally been close to those produced in the U.S.

- Outliers in the Data Set - There are a small number of data outliers in the Canadian data set that have a significant impact on the damage functions computed for each industry and sector. Oil and gas extraction provides a suitable example of a data outlier. Mining operations generally yield low customer damage functions; however, the mining industry customer damage function is relatively high because interruption cost estimates for the gas and oil extraction SIC group are three times higher than any other group included in the University of Saskatchewan study. Further, data verification and analysis was found to be extremely difficult because the data were collected nearly 10 years ago, and company-level data are not available.

- Missing Data - The University of Saskatchewan study produced interruption cost estimates for roughly half the industry groups identified in the U.S. SIC system. To fill data gaps, peer groups were established based on business operations and demand characteristics. Representative industry data were then used as a proxy for interruption costs within groups with missing data. To the extent that any assumptions about cost comparability are inaccurate, miscalculations result in erroneous results.

- Various Weighting Procedures - Numerous factors (e.g., GDP, gross output and electricity consumption) were used to weight SIC group data to produce industry and sector customer damage functions. Generally, electricity consumption is the most suitable factor used to weight data to produce industry and sector cost estimates. However, electricity consumption data were only available for the manufacturing industry. Thus, gross economic measures were used to weight the vast majority of the GCDFs. To the extent that the various weighting factors are unrepresentative of consumption of electricity, the use of these factors reduces the accuracy of the study findings.

- Use of $\$ / \mathrm{kW}$ Cost Parameter - The $\$ / \mathrm{kW}$ value is the most common cost parameter used to normalize data in interruption cost studies. It allows for the aggregation of study results by dividing the sum of the constituent costs by the sum of annual peak demands of study respondents. Data 
presented in terms of $\$ / \mathrm{kW}$ provides readily adaptable information for industrial, commercial or residential consumers, provided peak demand is known. There are, however, shortcomings to this approach. To the extent that the relationship between average and peak demand varies between industries, those industries characterized by fairly constant load demand will show relatively higher cost estimates. Further, energy intensive industries may experience extraordinarily high costs in the event of a power interruption; however, high costs can be washed away when dividing them by high peak load values. Thus, without knowledge of the demand characteristics of individual industries, the $\$ / \mathrm{kW}$ cost parameter fails to provide easily understandable cost comparisons between sectors and industries.

The accuracy of the results of the analysis could be enhanced dramatically with the collection of detailed survey data from energy consumers in the U.S. The survey could be designed in a manner that guarantees a statistically significant sample of customers within each industry identified in the SIC system or North American Industry Classification System (NAICS). 


\subsection{Conclusions}

Although limited by constraints in the data used, the findings of the analysis presented in this report indicate that an interruption in power supply can result in enormous costs to end-users in the industrial, commercial and transportation sectors. Direct costs include lost production, idle facilities and labor, damage to electronic data, damaged or spoiled product, damage to equipment or customer refunds. Indirect costs can include accidental injuries, looting, vandalism, legal costs, medical costs, insurance costs and loss of water supply. Further, residential customers may experience direct out-of-pocket expenses, including the purchase of wood for home heating, alternative light sources, food spoilage and damage to electrical equipment.

The findings of this and all other studies of interruption costs conclude that outage costs vary significantly based on the demand characteristics of the end-user. The analysis presented in this report suggests that interruption costs are highest in the transportation sector at $\$ 16.42 / \mathrm{kW}$ for a 1-hour interruption, followed by the industrial sector $(\$ 13.93 / \mathrm{kW})$ and the commercial sector $(\$ 12.87 / \mathrm{kW})$, also for 1 -hr. interruption. Residential customers incur costs $(\$ 0.15 / \mathrm{kW}$ for a 1-hour interruption) that are a fraction of those incurred by end-users in the other sectors.

While the costs associated with improved system reliability through investment in new facilities and equipment are well documented, the benefits that accrue to the U.S. economy as a result of improved system reliability are more difficult to quantify with precision. However, the findings of this and other studies cited in Introduction of the report indicate that the societal worth of electric power system reliability is significant.

Distributed energy resources operating both as part of the utility network and in the off-grid (or gridindependent) mode offer the potential to substantially mitigate the costs of grid unreliability. DER's greatest value may be that it offers the unique flexibility to choose combinations of cost and reliability across a broad spectrum to fit the needs of the end-user. For example, DER has already found markets at the "high" end of the spectrum in the so-called premium power market where very expensive UPS systems are a good investment. Most UPS systems can be considered DER. Indeed, the results contained in this report point to and highlight why certain industrial and commercial sectors and specific end-users have already invested in and continue to invest in UPS DER systems. These systems ensure that manufacturing processes, for example, will not be interrupted by even momentary power outages so that product will not have to be scrapped, process equipment cleaned and processing restarted, sometimes at considerable cost. In most of these applications, power is never delivered to the grid, although, of course, the end-user remains connected to the grid and receives power from the grid. For example, UPS systems that include diesel-generator sets may appear to be logical candidates for continuous operation, selling power back to the grid, provided that the UPS function is not compromised. However, the economics and environmental issues tend to be situation specific and therefore, to date, most owners of UPS systems focus their UPS assets on the fundamental value proposition - mitigating or eliminating the costs to their businesses associated with the loss of grid power. Thus, most of the issues surrounding the interconnection, integration, operation and control of distributed energy resources as active power sources supplying the distribution network can be and are avoided. 
During the last 20 years, utilities and researchers have begun to understand the value in the collection and analysis of interruption cost data. The continued investigation of the monetary impact of power outages will facilitate the advancement of the analytical methods used to measure the costs and benefits from the perspective of the energy consumer. More in-depth analysis may be warranted because of the privatization and deregulation of power utilities, price instability in certain regions of the U.S. and the continued evolution of alternative auxiliary power systems. 


\subsection{Bibliography}

Billinton, R. 2001 "Methods to Consider Customer Interruption Costs in Power System Analysis." Conseil International des Grands Réseaux Électriques (CIGRE). Paris, France.

Billinton, R. and R. Allan. 1988. Reliability Assessment of Large Electric Power Systems. Kluwer Academic Publishers, Dordrecht, Netherlands.

Billinton R., E. Chan, G. Tollefson and G. Wacker. 1994. "A Canadian Customer Survey to Assess Power System Reliability Worth.” IEEE Transaction on Power Systems, Vol. 9, No. 1, pp. 443-450.

Billinton, R., E. Chan and G. Wacker. 1994. "Probability Distribution Approach to Describe Customer Costs Due to Electric Supply Interruptions.” IEE Proceedings Generation, Transmission and Distribution, Vol. 141, No. 6, pp. 594598.

Billinton, R. and M. Pandey. 1999. "Reliability Worth Assessment in a Developing Country Residential Survey Results.” IEEE Transactions on Power Systems, 14(4):1226-1232.

Billinton, R. and G. Wacker. 1989. "Customer Cost of Electric Service Interruptions.” IEEE Proceedings, Vol. 77, No. 6, pp. 919-930. Institute of Electrical and Electronics Engineers (IEEE), New York.

Blair, P. and J. Cowin. 1979. "Cost of Power Outages-The 1977 New York City Blackout.” Presented at the IEEE Industrial and Commercial Power Systems Technical Conference, Seattle, Washington.

Dali, V., S. Dialynas and S. Megaloconomos. 2001. "Interruption Cost Analysis for the Electrical Power Customers in Greece." Proceedings of the Congrés International des Réseaux Électriques de Distribution 2001 Conference, Amsterdam, The Netherlands. CIRED, Brussels, Belgium.

Electric Power Research Institute (EPRI), Consortium for Electric Infrastructure to Support a Digital Society. The Cost of Power Disturbance to Industrial and Digital Economy Companies. Palo Alto, California. (2001).

Gannon, P. 1976. "Cost of Interruptions: Economic Evaluation of Reliability.” I\&CPS Technical Conference, Los Angeles, California. Institute of Electrical and Electronics engineers, New York.

Goel, L. 1998. "Power System Reliability Cost/Benefit Assessment and Application in Perspective." Computers and Electrical Engineering 24: pp 315-324.

Jenkins, G., H. Lim and P. Shukla. 1999. "Evaluation of an Expansion of the Electricity Transmission System in Mexico.” Development Discussion Paper No. 688. Harvard Institute for International Development, Cambridge, Massachusetts.

Lehtonen, M. and B. Lemstrom. 1995. 'Comparison of the Methods for Assessing the Customers' Outage Costs.” VTT Energy. Jyvaskyla, Finland. 
New York City Office of Economic Development. 1977. Statistical Profile of Emergency Aid Commission Applications.” New York.

Ontario Hydro. 1977. "Ontario Hydro Survey on Power System Reliability: Viewpoint of Large Users." Report No. PMA 76-5, Toronto, Canada.

Shipley, R., A. Patton and J. Denison. 1972. “Power Reliability Cost Versus Worth.” IEEE Transactions on Power Apparatus and Systems, Vol. 91, pp. 2204-2212.

Stephens, Inc. 2000. "Powering the Digital Economy: Digital Power Demand Meets Industrial Power." Little Rock, Arkansas.

Stoll, H. 1989. Least Cost Utility Planning. Josey-Bass, New York.

Systems Control, Inc. 1978. "Impact Assessment of the 1977 New York City Blackout." Prepared for United States Department of Energy, by Systems Control Inc., Palo Alto, California.

Train, K. and Chi-Keung Woo. 1988. "The Cost of Electric Power Interruptions to Commercial Firms." The Energy Journal, 9(3):161-172.

United States Congress. 1990. 'Physical Vulnerability of Electric Systems to Natural Disasters and Sabotage." Office of Technology Assessment, OTA-E-453, Washington D.C.

United States Department of Energy. 2000. “Strategic Plan for Distributed Energy Resources.” Washington D.C.

United States Department of Energy, Energy Information Administration. 2000. “2000 Annual Energy Review." Washington D.C.

United States Department of Energy, Energy Information Administration. 2001. "Monthly Energy Review September 2001.” Washington D.C.

United States Department of Energy, Energy Information Administration. 1999. "Annual Energy Outlook 2000." Washington D.C.

Willis, H. Lee and Walter G. Scott. 2000. Distributed Power Generation: Planning and Evaluation, Marcel Dekker, Inc., New York. 
Appendix A

\section{Data}





\section{Appendix A - Data}

Table A-1. Group Customer Damage Functions (1996 US\$/kW)

\begin{tabular}{|c|c|c|c|c|}
\hline SIC Code & Description & Durati & n of Intern & ption \\
\hline & & 20 Minutes & 1Hour & 4 Hours \\
\hline & Agricultural products - crops & 0.02 & 0.12 & 1.28 \\
\hline 02 & Agricultural production livestock & 0.05 & 0.24 & 1.81 \\
\hline 07 & Agricultural service & 1.34 & 2.11 & 4.66 \\
\hline 08 & Forestry & 0.02 & 0.12 & 1.28 \\
\hline 09 & Fishing, hunting and trapping & 0.02 & 0.12 & 1.28 \\
\hline 10 & Metal mining & 1.34 & 2.11 & 4.66 \\
\hline 12 & Coal mining & 1.34 & 2.11 & 4.66 \\
\hline 13 & Oil and gas extraction & 81.47 & 193.88 & 205.85 \\
\hline 14 & Mining and quarrying of nonmetallic minerals & 2.96 & 3.74 & 8.31 \\
\hline $15-17$ & Construction & 1.34 & 2.11 & 4.66 \\
\hline 20 & Food and kindred products & 4.74 & 15.10 & 50.52 \\
\hline 21 & Tobacco manufactures & 3.24 & 5.37 & 23.76 \\
\hline 22 & Textile mill products & 3.24 & 5.37 & 23.76 \\
\hline 23 & Apparel and other finished products made from fabrics & 2.03 & 6.10 & 25.13 \\
\hline 24 & Wood products & 1.18 & 2.22 & 7.27 \\
\hline 25 & Furniture and fixtures & 10.43 & 21.48 & 52.47 \\
\hline 26 & Paper and allied products & 4.79 & 5.29 & 12.71 \\
\hline 27 & Printing and publishing & 2.49 & 4.68 & 14.14 \\
\hline 28 & Chemicals and allied products & 1.70 & 3.27 & 17.93 \\
\hline 29 & Petroleum and coal products & 1.70 & 3.27 & 17.93 \\
\hline 30 & Rubber and miscellaneous plastic products & 0.78 & 1.26 & 4.52 \\
\hline 31 & Leather and leather products & 0.00 & 1.64 & 20.84 \\
\hline 32 & Stone, clay, glass, and concrete products & 2.90 & 7.22 & 28.81 \\
\hline 33 & Primary metal industries & 1.55 & 2.49 & 5.26 \\
\hline 34 & Fabricated metal products & 4.57 & 9.16 & 42.07 \\
\hline 35 & Industrial machinery and equipment & 3.02 & 5.40 & 18.45 \\
\hline 36 & Electrical and electronic equipment & 3.48 & 6.60 & 19.89 \\
\hline 37 & Transportation equipment & 9.61 & 23.67 & 185.21 \\
\hline 38 & Instruments and related products & 3.02 & 5.40 & 18.45 \\
\hline 39 & Miscellaneous manufacturing industries & 13.38 & 10.76 & 38.71 \\
\hline 40 & Railroad transportation & 1.55 & 2.49 & 5.26 \\
\hline 41 & Local and suburban transit and hwy passenger transport & 1.55 & 2.49 & 5.26 \\
\hline 42 & Motor freight transportation and warehousing & 1.55 & 2.49 & 5.26 \\
\hline 44 & Water transportation & 1.55 & 2.49 & 5.26 \\
\hline 45 & Transportation by air & 19.41 & 41.68 & 118.21 \\
\hline 46 & Pipelines, except natural gas & 9.61 & 23.67 & 185.21 \\
\hline 47 & Transportation services & 24.16 & 29.39 & 58.49 \\
\hline 48 & Communications & 19.41 & 41.68 & 118.21 \\
\hline 49 & Electric, gas and sanitary services & 1.54 & 11.32 & 33.19 \\
\hline
\end{tabular}


Table A-1. Group Customer Damage Functions (1996 US\$/kW) - continued

\begin{tabular}{|c|c|c|c|}
\hline \begin{tabular}{l|l}
$50-51$ & Wholesale trade
\end{tabular} & 1.54 & 11.32 & 33.19 \\
\hline \begin{tabular}{l|l}
52 & Building materials
\end{tabular} & 11.87 & 35.92 & 161.59 \\
\hline \begin{tabular}{l|l|}
53 & G eneral merchandise \\
\end{tabular} & 13.23 & 21.14 & 228.15 \\
\hline \begin{tabular}{l|l}
54 & Food stores \\
\end{tabular} & 9.47 & 28.41 & 147.93 \\
\hline \begin{tabular}{l|l}
55 & Automotive dealers and gasoline service stations
\end{tabular} & 11.87 & 35.92 & 161.59 \\
\hline \begin{tabular}{l|l}
56 & Apparel and accessory stores \\
\end{tabular} & 4.43 & 13.29 & 88.60 \\
\hline 57 Home furniture, furnishings and equipment stores & 0.57 & 8.00 & 39.76 \\
\hline 58 E ating and drinking places & 9.47 & 28.41 & 147.93 \\
\hline \begin{tabular}{l|l|}
59 & Miscellaneous retail \\
\end{tabular} & 1.54 & 11.32 & 33.19 \\
\hline \begin{tabular}{l|l}
60 & D epository institutions \\
\end{tabular} & 1.93 & 5.67 & 17.50 \\
\hline \begin{tabular}{l|l}
61 & Nondepository credit institutions \\
\end{tabular} & 1.93 & 5.67 & 17.50 \\
\hline \begin{tabular}{l|l}
62 & Security and commodity brokers, dealers and services \\
\end{tabular} & 1.93 & 5.67 & 17.50 \\
\hline 63 Insurance carriers & 0.00 & 7.31 & 29.23 \\
\hline \begin{tabular}{l|l}
64 & Insurance agents, brokers and service
\end{tabular} & 24.16 & 29.39 & 58.49 \\
\hline \begin{tabular}{l|l}
65 & Real estate \\
\end{tabular} & 1.22 & 1.85 & 12.16 \\
\hline \begin{tabular}{l|l}
67 & Holding and other investment offices \\
\end{tabular} & 0.00 & 8.46 & 33.83 \\
\hline 70 Hotels, rooming houses, camps and other lodging & 0.41 & 1.13 & 3.05 \\
\hline \begin{tabular}{l|l|}
72 & Personal services \\
\end{tabular} & 1.36 & 2.39 & 13.22 \\
\hline \begin{tabular}{l|l|}
73 & Business services \\
\end{tabular} & 19.41 & 41.68 & 118.21 \\
\hline 75 Automotive repair, services and parking & 11.87 & 35.92 & 161.59 \\
\hline \begin{tabular}{l|l}
76 & Miscellaneous repair services
\end{tabular} & 1.54 & 11.32 & 33.19 \\
\hline $\begin{array}{ll}78 & \text { Motion pictures } \\
\end{array}$ & 1.07 & 63.83 & 78.01 \\
\hline 79 Amusement and recreation services & 1.07 & 63.83 & 78.01 \\
\hline 80 Health services & 2.38 & 3.02 & 4.38 \\
\hline \begin{tabular}{l|l}
81 & Legal services \\
\end{tabular} & 2.38 & 3.02 & 4.38 \\
\hline \begin{tabular}{l|l|l}
82 & Educational services \\
\end{tabular} & 0.30 & 1.13 & 4.27 \\
\hline \begin{tabular}{l|l}
83 & Social services \\
\end{tabular} & 2.38 & 3.02 & 4.38 \\
\hline \begin{tabular}{l|l}
86 & Membership organizations \\
\end{tabular} & 0.30 & 1.13 & 4.27 \\
\hline \begin{tabular}{l|l|l}
$84,87,89$ & O ther services \\
\end{tabular} & 4.26 & 12.29 & 50.43 \\
\hline \begin{tabular}{l|l}
88 & Private households \\
\end{tabular} & 0.03 & 0.15 & 1.64 \\
\hline State government & 5.05 & 8.36 & 19.84 \\
\hline Federal government & 0.24 & 5.16 & 20.05 \\
\hline
\end{tabular}


Table A-2. Average Energy Interruption Costs for 1994 Weighted by Total Share of Electricity Purchased - Manufacturing Sector

\begin{tabular}{|c|c|c|c|c|c|c|c|c|c|c|}
\hline \multicolumn{11}{|c|}{ Duration of Interruption } \\
\hline & 0 Minutes & $1 \mathrm{Ho}$ & & & & & 4 Hour & & & \\
\hline $\begin{array}{l}\text { SIC } \\
\text { Code }\end{array}$ & SIC Description & $\begin{array}{c}\text { Electric } \\
\text { PQ } \\
\text { Purchases } \\
\text { (MWh) }\end{array}$ & \begin{tabular}{|c|} 
Share of \\
Total \\
Electric \\
PQ \\
Purchases \\
(\%) \\
\end{tabular} & \begin{tabular}{|c|} 
Price \\
$(\$ / \mathrm{kWh})$
\end{tabular} & $\begin{array}{c}\text { Intemuption } \\
\text { Cost } \\
(\$ / \mathbf{k W})\end{array}$ & \begin{tabular}{|c|} 
Weighted \\
Intemuption \\
Cost \\
$(\$ / \mathbf{k W})$ \\
\end{tabular} & $\begin{array}{c}\text { Intemuption } \\
\text { Cost } \\
\text { (\$/ kW) }\end{array}$ & \begin{tabular}{|c|} 
Weighted \\
Intermuption \\
Cost \\
$(\$ / \mathrm{kW})$ \\
\end{tabular} & $\begin{array}{c}\text { Intemuption } \\
\text { Cost } \\
(\$ / \mathbf{k W})\end{array}$ & $\begin{array}{c}\text { Weighted } \\
\text { Intemuption } \\
\text { Cost } \\
(\$ / \mathbf{k W})\end{array}$ \\
\hline 20 & $\begin{array}{l}\text { Food } \\
\text { products }\end{array}$ & $59,044,700$ & 7.4 & 0.0543 & 4.74 & 0.35 & 15.10 & 1.11 & 50.52 & 3.72 \\
\hline 21 & $\begin{array}{l}\text { Tobacco } \\
\text { manufacturers }\end{array}$ & $1,442,100$ & 0.2 & 0.0494 & 3.24 & 0.01 & 5.37 & 0.01 & 23.76 & 0.04 \\
\hline 22 & $\begin{array}{l}\text { Textile mill } \\
\text { produds }\end{array}$ & $34,301,700$ & 4.3 & 0.0484 & 3.24 & 0.14 & 5.37 & 0.23 & 23.76 & 1.02 \\
\hline 23 & \begin{tabular}{|l|} 
Apparel and \\
other finished \\
products \\
made from \\
fabrics
\end{tabular} & $8,736,700$ & 1.1 & 0.0713 & 2.03 & 0.02 & 6.10 & 0.07 & 25.13 & 0.27 \\
\hline 24 & $\begin{array}{l}\text { Wood } \\
\text { products }\end{array}$ & $22,511,700$ & 2.8 & 0.0518 & 1.18 & 0.03 & 2.22 & 0.06 & 7.27 & 0.20 \\
\hline 25 & $\begin{array}{l}\text { Furniture and } \\
\text { fixtures }\end{array}$ & $6,523,800$ & 0.8 & 0.0624 & 10.43 & 0.08 & 21.48 & 0.17 & 52.47 & 0.43 \\
\hline 26 & $\begin{array}{l}\text { Paper and } \\
\text { allied } \\
\text { products }\end{array}$ & $72,053,200$ & 9.0 & 0.0422 & 4.79 & 0.43 & 5.29 & 0.48 & 12.71 & 1.14 \\
\hline 27 & $\begin{array}{l}\text { Printing and } \\
\text { publishing }\end{array}$ & $18,497,000$ & 2.3 & 0.0639 & 2.49 & 0.06 & 4.68 & 0.11 & 14.14 & 0.33 \\
\hline 28 & \begin{tabular}{|l|} 
Chemicals and \\
allied \\
products
\end{tabular} & $152,860,000$ & 19.1 & 0.0359 & 1.70 & 0.32 & 3.27 & 0.62 & 17.93 & 3.42 \\
\hline 29 & $\begin{array}{l}\text { Petroleum } \\
\text { and coal } \\
\text { products }\end{array}$ & $34,916,400$ & 4.4 & 0.0441 & 1.70 & 0.07 & 3.27 & 0.14 & 17.93 & 0.78 \\
\hline 30 & \begin{tabular}{|l|} 
Rubber and \\
miscellaneous \\
plastics \\
products
\end{tabular} & $44,211,600$ & 5.5 & 0.0560 & 0.78 & 0.04 & 1.26 & 0.07 & 4.52 & 0.25 \\
\hline 31 & $\begin{array}{l}\text { Leather and } \\
\text { leather } \\
\text { products }\end{array}$ & 938,200 & 0.1 & 0.0645 & & - & 1.64 & 0.00 & 20.84 & 0.02 \\
\hline 32 & $\begin{array}{l}\text { Stone, clay, } \\
\text { glass, and } \\
\text { concrete } \\
\text { products }\end{array}$ & $35,083,300$ & 4.4 & 0.0483 & 2.90 & 0.13 & 7.22 & 0.32 & 28.81 & 1.26 \\
\hline 33 & $\begin{array}{l}\text { Primary metal } \\
\text { industries }\end{array}$ & $143,156,600$ & 17.9 & 0.0347 & 1.55 & 0.28 & 2.49 & 0.45 & 5.26 & 0.94 \\
\hline
\end{tabular}


Table A-2. Average Energy Interruption Costs for 1994 Weighted by Total Share of Electricity Purchased - Manufacturing Sector - continued

\begin{tabular}{|c|c|c|c|c|c|c|c|c|c|c|}
\hline 4 & \begin{tabular}{|l} 
Fabricated \\
metal \\
products
\end{tabular} & $33,880,800$ & 4.2 & 0.0615 & 4.57 & 0.19 & 9.16 & 0.39 & 42.07 & 1.78 \\
\hline 35 & $\begin{array}{l}\text { Industrial } \\
\text { machinery } \\
\text { and } \\
\text { equipment }\end{array}$ & $36,602,800$ & 4.6 & 0.0591 & 3.02 & 0.14 & 5.40 & 0.25 & 18.45 & 0.84 \\
\hline 36 & $\begin{array}{l}\text { Electrical and } \\
\text { electronic } \\
\text { equipment } \\
\end{array}$ & $35,580,900$ & 4.4 & 0.0567 & 3.48 & 0.15 & 6.60 & 0.29 & 19.89 & 0.88 \\
\hline 37 & $\begin{array}{l}\text { Transportatio } \\
\text { n equipment }\end{array}$ & $41,943,300$ & 5.2 & 0.0522 & 9.61 & 0.50 & 23.67 & 1.24 & 185.21 & 9.70 \\
\hline 38 & $\begin{array}{l}\text { Instruments } \\
\text { and related } \\
\text { products }\end{array}$ & $13,627,100$ & 1.7 & 0.0664 & 3.02 & 0.05 & 5.40 & 0.09 & 18.45 & 0.31 \\
\hline 39 & $\begin{array}{l}\text { Miscellaneous } \\
\text { manufacturing } \\
\text { industries }\end{array}$ & $5,037,600$ & 0.6 & 0.0650 & 13.38 & 0.08 & 10.76 & 0.07 & 38.71 & 0.24 \\
\hline & Total & $800,949,500$ & 100.0 & & & 3.09 & & 6.17 & & 27.60 \\
\hline
\end{tabular}


Table A-3. Energy Interruption Costs for 1994Weighted by Total Share of Gross Domestic Product or Gross Output

\begin{tabular}{|c|c|c|c|c|c|c|c|c|}
\hline $\begin{array}{l}\text { SIC } \\
\text { Code }\end{array}$ & SIC Description & \begin{tabular}{|c|} 
GDP \\
(\$Billions \\
- 1996)
\end{tabular} & $\begin{array}{c}\text { Share of } \\
\text { Group } \\
\text { GDP } \\
(\%) \\
\end{array}$ & \begin{tabular}{|c|} 
Output \\
(\$Billions \\
- 1996) \\
\end{tabular} & \begin{tabular}{|c|} 
Share of \\
Sector \\
Output \\
(\%) \\
\end{tabular} & \begin{tabular}{|c|} 
Weighted \\
Interruption \\
Costs \\
$(\$ / \mathrm{kW})$ \\
\end{tabular} & \begin{tabular}{|c|} 
Weighted \\
Interruption \\
Costs \\
$(\$ / \mathbf{k W})$ \\
\end{tabular} & $\begin{array}{c}\text { Weighted } \\
\text { Interruption } \\
\text { Costs } \\
(\$ / \mathbf{k W}) \\
\end{array}$ \\
\hline & & & & & & \multicolumn{3}{|c|}{ Duration of Interruption } \\
\hline & & & & & & 20 Minutes & 1Hour & 4 Hours \\
\hline 01 & $\begin{array}{l}\text { Agriculture } \\
\text { products - crops }\end{array}$ & & & 71.8 & 40.3 & 0.01 & 0.05 & 0.52 \\
\hline & $\begin{array}{l}\text { Agriculture } \\
\text { production - } \\
\text { livestock }\end{array}$ & & & 76.0 & 42.6 & 0.02 & 0.10 & 0.77 \\
\hline & $\begin{array}{l}\text { Agriculture } \\
\text { service }\end{array}$ & & & 22.9 & 12.9 & 0.17 & 0.27 & 0.60 \\
\hline & Forestry & & & 4.3 & 2.4 & 0.00 & 0.00 & 0.03 \\
\hline & $\begin{array}{l}\text { Fishing, hunting } \\
\text { and trapping }\end{array}$ & & & 3.1 & 1.8 & 0.00 & 0.00 & 0.02 \\
\hline & Agriculture Total & 135.8 & & & & 0.20 & 0.43 & 1.94 \\
\hline 10 & Metal mining & 5.7 & 1.4 & & & 0.02 & 0.03 & 0.07 \\
\hline 12 & Coal Mining & 9.6 & 2.4 & & & 0.03 & 0.05 & 0.11 \\
\hline 13 & \begin{tabular}{|l|} 
Oil and $G$ as \\
Extraction \\
\end{tabular} & 83.8 & 20.7 & & & 16.84 & 40.08 & 42.55 \\
\hline 14 & $\begin{array}{l}\text { Mining and } \\
\text { quarrying of non } \\
\text { metallic minerals }\end{array}$ & 9.1 & 2.2 & & & 0.07 & 0.08 & 0.19 \\
\hline $15-17$ & Construction & 297.2 & 73.3 & & & 0.98 & 1.54 & 3.42 \\
\hline & \begin{tabular}{|l} 
Mining and \\
Construction \\
Total \\
\end{tabular} & 405.4 & & & & 17.9 & 41.78 & 46.33 \\
\hline $20-39$ & $\begin{array}{l}\text { Manufacturing } \\
\text { Total }\end{array}$ & $1,218.9$ & & & & 3.1 & 6.17 & 27.60 \\
\hline 40 & $\begin{array}{l}\text { Railroad } \\
\text { Transportation }\end{array}$ & 22.1 & 10.1 & & & 0.16 & 0.25 & 0.53 \\
\hline 41 & $\begin{array}{l}\text { Local and } \\
\text { suburban transit } \\
\text { and hwy } \\
\text { passenger } \\
\text { transport } \\
\end{array}$ & 12.8 & 5.9 & & & 0.09 & 0.15 & 0.31 \\
\hline 42 & $\begin{array}{l}\text { Motor freight } \\
\text { transportation } \\
\text { and warehousing }\end{array}$ & 85.3 & 39.0 & & & 0.61 & 0.97 & 2.05 \\
\hline 44 & $\begin{array}{l}\text { Water } \\
\text { transportation }\end{array}$ & 11.3 & 5.2 & & & 0.08 & 0.13 & 0.27 \\
\hline 45 & $\begin{array}{l}\text { Transportation } \\
\text { by air }\end{array}$ & 59.6 & 27.3 & & & 5.29 & 11.36 & 32.21 \\
\hline
\end{tabular}


Table A-3. Energy Interruption Costs Weighted by Total Share of Gross Domestic Product or Gross Output - continued

\begin{tabular}{|c|c|c|c|c|c|c|c|c|}
\hline 46 & $\begin{array}{l}\text { Pipelines, except } \\
\text { natural gas }\end{array}$ & 5.5 & 2.5 & & & 0.24 & 0.60 & 4.66 \\
\hline 47 & $\begin{array}{l}\text { Transportation } \\
\text { services }\end{array}$ & 22.1 & 10.1 & & & 2.44 & 2.97 & 5.91 \\
\hline & $\begin{array}{l}\text { Total } \\
\text { Transportation }\end{array}$ & 218.7 & & & & 8.91 & 16.42 & 45.95 \\
\hline 48 & Communications & 190.8 & 22.0 & & & 4.26 & 9.15 & 25.95 \\
\hline 49 & $\begin{array}{l}\text { Electric, gas and } \\
\text { sanitary services }\end{array}$ & 196.7 & 22.6 & & & 0.35 & 2.56 & 7.51 \\
\hline $50-51$ & Wholesale trade & 481.6 & 55.4 & & & 0.85 & 6.27 & 18.39 \\
\hline & $\begin{array}{l}\text { Commercial, utilit } \\
\text { and wholesale trad } \\
\text { Total }\end{array}$ & 869.1 & & & & 5.5 & 17.99 & 51.86 \\
\hline 52 & $\begin{array}{l}\text { Building } \\
\text { materials }\end{array}$ & & & 27.2 & 4.5 & 0.5 & 1.6 & 7.3 \\
\hline 53 & $\begin{array}{l}\text { G eneral } \\
\text { merchandise }\end{array}$ & & & 60.6 & 10.0 & 1.3 & 2.1 & 22.9 \\
\hline 54 & Food stores & & & 83.8 & 13.9 & 1.3 & 3.9 & 20.6 \\
\hline 55 & $\begin{array}{l}\text { Automotive } \\
\text { dealers and } \\
\text { gasoline service } \\
\text { stations }\end{array}$ & & & 104.1 & 17.3 & 2.0 & 6.2 & 27.9 \\
\hline 56 & $\begin{array}{l}\text { A pparel and } \\
\text { accessory stores }\end{array}$ & & & 35.2 & 5.8 & 0.3 & 0.8 & 5.2 \\
\hline 57 & $\begin{array}{l}\text { Home furniture, } \\
\text { furnishings and } \\
\text { equipment stores }\end{array}$ & & & 32.5 & 5.4 & 0.0 & 0.4 & 2.1 \\
\hline & $\begin{array}{l}\text { Eating and } \\
\text { drinking places }\end{array}$ & & & 169.2 & 28.1 & 2.7 & 8.0 & 41.5 \\
\hline 59 & $\begin{array}{l}\text { Miscellaneous } \\
\text { retail }\end{array}$ & & & 90.5 & 15.0 & 0.2 & 1.7 & 5.0 \\
\hline & Retail Total & & & & & 8.4 & 24.8 & 132.4 \\
\hline 60 & $\begin{array}{l}\text { D epository } \\
\text { Institutions }\end{array}$ & 227.9 & 8.2 & & & 0.16 & 0.46 & 1.43 \\
\hline 61 & $\begin{array}{l}\text { Nondepository } \\
\text { credit institutions }\end{array}$ & 29.9 & 1.1 & & & 0.02 & 0.06 & 0.19 \\
\hline 62 & $\begin{array}{l}\text { Security and } \\
\text { commodity } \\
\text { brokers, dealers } \\
\text { and services }\end{array}$ & 75.9 & 2.7 & & & 0.05 & 0.15 & 0.48 \\
\hline 63 & Insurance carriers & 127.7 & 4.6 & & & & 0.33 & 1.34 \\
\hline 64 & $\begin{array}{l}\text { Insurance agents, } \\
\text { brokers and } \\
\text { service }\end{array}$ & 51.6 & 1.8 & & & 0.45 & 0.54 & 1.08 \\
\hline
\end{tabular}


Table A-3. Energy Interruption Costs Weighted by Total Share of Gross Domestic Product or Gross Output - continued

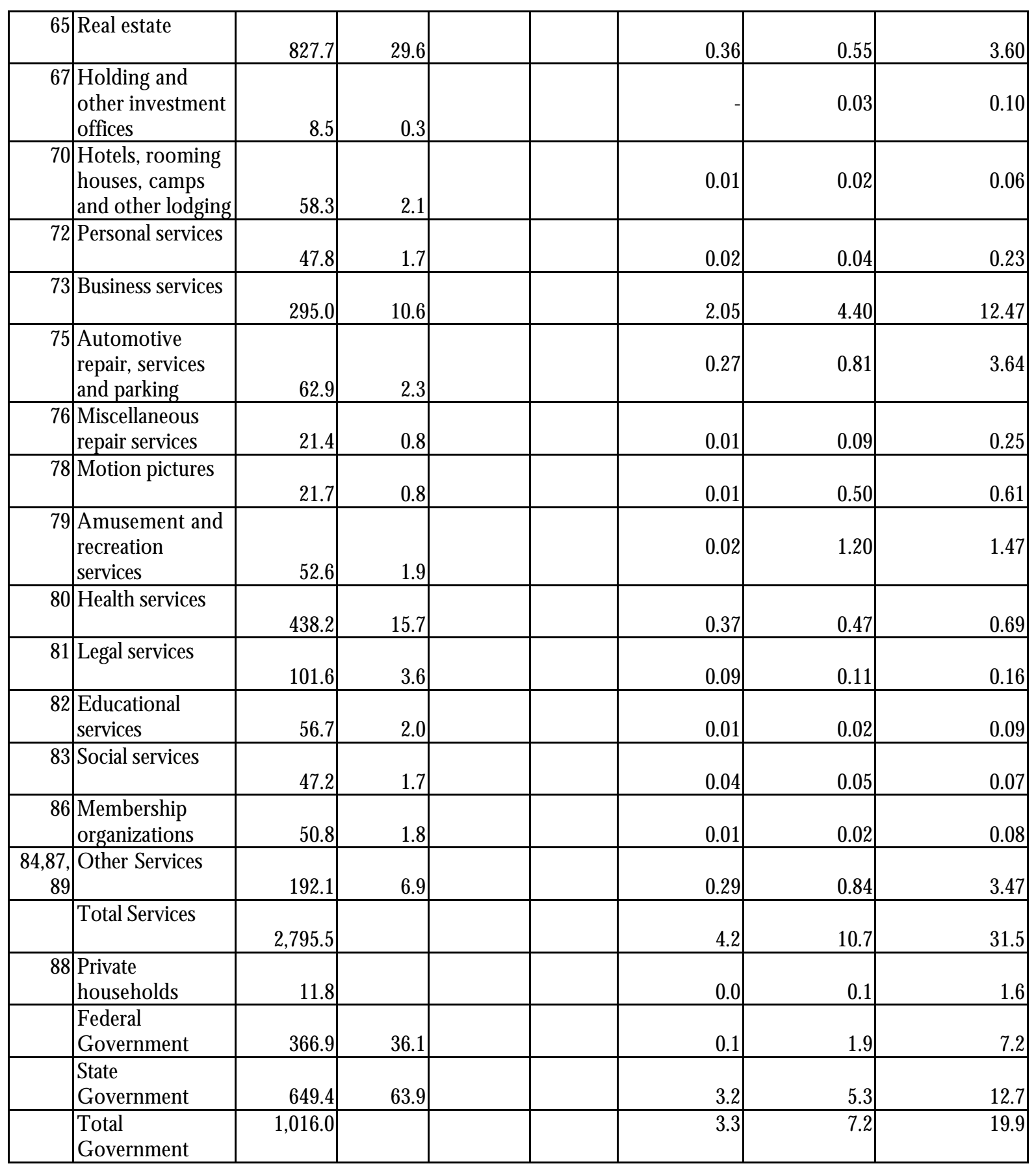


Table A 4. Interruption Cost Data by SIC Code (1996 US\$/Peak Annual kW Load)

\begin{tabular}{|c|c|c|c|c|c|}
\hline SIC & SIC Description & $\overline{\text { Dura }}$ & ation (hr & & Basis of Estimate if Different \\
\hline & & 0.33 & 1.00 & 4.00 & \\
\hline 01 & Agricultural products-- crops & 0.02 & 0.12 & $\overline{1.28}$ & \\
\hline 02 & Agricultural production livestock & 0.05 & 0.24 & 1.81 & \\
\hline 07 & Agricultural service & 1.34 & 2.11 & 4.66 & Mining \\
\hline 08 & Forestry & 0.02 & 0.12 & 1.28 & Agricultural Crops \\
\hline 09 & Fishing, hunting and trapping & 0.02 & 0.12 & $\overline{1.28}$ & Agricultural Crops \\
\hline 10 & Metal mining & 1.34 & 2.11 & 4.66 & \\
\hline 12 & Coal Mining & 1.34 & 2.11 & $\overline{4.66}$ & \\
\hline 13 & Oil and $\mathrm{G}$ as Extraction & 81.47 & 193.88 & 205.85 & \\
\hline 14 & $\begin{array}{l}\text { Mining and quarrying of nonmetallic } \\
\text { minerals }\end{array}$ & 2.96 & 3.74 & 8.31 & \\
\hline $15-17$ & Construction & 1.34 & 2.11 & 4.66 & Mining \\
\hline 20 & Food and Kindred Products & 4.74 & 15.10 & 50.52 & \\
\hline 21 & Tobacco manufactures & 3.24 & 5.37 & $\overline{23.76}$ & Textiles \\
\hline 22 & Textile mill products & 3.24 & 5.37 & 23.76 & \\
\hline 23 & $\begin{array}{l}\text { Apparel and O ther Finished Products Made } \\
\text { from Fabrics }\end{array}$ & 2.03 & 6.10 & 25.13 & \\
\hline 24 & Wood Products & 1.18 & 2.22 & 7.27 & \\
\hline 25 & Furniture and fixtures & 10.43 & 21.48 & 52.47 & \\
\hline 26 & Paper and allied products & 4.79 & 5.29 & 12.71 & \\
\hline 27 & Printing and publishing & 2.49 & 4.68 & 14.14 & \\
\hline 28 & Chemicals and allied products & 1.70 & 3.27 & 17.93 & \\
\hline 29 & Petroleum and coal products & 1.70 & 3.27 & 17.93 & Chemical and Allied Products \\
\hline 30 & Rubber and Miscellaneous Plastic Products & 0.78 & 1.26 & $\overline{4.52}$ & \\
\hline 31 & Leather and leather products & 0.00 & 1.64 & 20.84 & \\
\hline 32 & Stone, clay, glass, and concrete products & 2.90 & 7.22 & 28.81 & \\
\hline 33 & Primary metal industries & 1.55 & 2.49 & 5.26 & \\
\hline 34 & Fabricated metal products & 4.57 & 9.16 & 42.07 & \\
\hline 35 & Industrial machinery and equipment & 3.02 & 5.40 & 18.45 & \\
\hline 36 & Electrical and electronic equipment & 3.48 & 6.60 & 19.89 & \\
\hline 37 & Transportation equipment & 9.61 & 23.67 & 185.21 & \\
\hline 38 & Instruments and related products & 3.02 & 5.40 & 18.45 & Industrial machinery and equipment \\
\hline 39 & Miscellaneous manufacturing industries & 13.38 & 10.76 & 38.71 & \\
\hline 40 & Railroad Transportation & 1.55 & 2.49 & $\overline{5.26}$ & Primary metals \\
\hline$\overline{41}$ & $\begin{array}{l}\text { Local and suburban transit and hwy } \\
\text { passenger transport }\end{array}$ & 1.55 & 2.49 & $\overline{5.26}$ & Primary metals \\
\hline 42 & $\begin{array}{l}\text { Motor freight transportation and } \\
\text { warehousing }\end{array}$ & 1.55 & 2.49 & 5.26 & Primary metals \\
\hline$\overline{44}$ & Water transportation & 1.55 & 2.49 & 5.26 & Primary metals \\
\hline 45 & Transportation by air & 19.41 & 41.68 & 118.21 & Business Services \\
\hline 46 & Pipelines, except natural gas & 9.61 & 23.67 & 185.21 & Transportation Equipment \\
\hline 47 & Transportation services & 24.16 & 29.39 & 58.49 & $\begin{array}{l}\text { Insurance agents, brokers and } \\
\text { service }\end{array}$ \\
\hline 48 & Communications & 19.41 & 41.68 & 118.21 & Business Services \\
\hline
\end{tabular}


Table A-4. Interruption Cost Data by SIC Code (1996 US\$/Peak Annual kW Load) - continued

\begin{tabular}{|c|c|c|c|c|c|}
\hline 49 & Electric, gas and sanitary services & 1.54 & 11.32 & 33.19 & Miscellaneous retail \\
\hline $50-51$ & Wholesale trade & 1.54 & 11.32 & 33.19 & Miscellaneous retail \\
\hline 52 & Building materials & 11.87 & 35.92 & 161.59 & $\begin{array}{l}\text { Automotive dealers and gasoline } \\
\text { service stations }\end{array}$ \\
\hline 53 & G eneral merchandise & 13.23 & 21.14 & 228.15 & \\
\hline 54 & Food stores & 9.47 & 28.41 & 147.93 & Eating and drinking places \\
\hline 55 & $\begin{array}{l}\text { Automotive dealers and gasoline service } \\
\text { stations }\end{array}$ & 11.87 & 35.92 & 161.59 & \\
\hline 56 & Apparel and accessory stores & 4.43 & 13.29 & 88.60 & \\
\hline 57 & $\begin{array}{l}\text { Home furniture, furnishings and equipment } \\
\text { stores }\end{array}$ & 0.57 & 8.00 & 39.76 & \\
\hline 58 & Eating and drinking places & 9.47 & 28.41 & 147.93 & \\
\hline 59 & Miscellaneous retail & 1.54 & 11.32 & 33.19 & \\
\hline 60 & D epository Institutions & 1.93 & 5.67 & 17.50 & \\
\hline 61 & Nondepository credit institutions & 1.93 & 5.67 & 17.50 & D epository institutions \\
\hline 62 & $\begin{array}{l}\text { Security and commodity brokers, dealers } \\
\text { and services }\end{array}$ & 1.93 & 5.67 & 17.50 & D epository institutions \\
\hline 63 & Insurance carriers & 0.00 & 7.31 & 29.23 & \\
\hline 64 & Insurance agents, brokers and service & 24.16 & 29.39 & 58.49 & \\
\hline 65 & Real estate & 1.22 & 1.85 & 12.16 & \\
\hline 67 & Holding and other investment offices & 0.00 & 8.46 & 33.83 & \\
\hline 70 & $\begin{array}{l}\text { Hotels, rooming houses, camps and other } \\
\text { lodging }\end{array}$ & 0.41 & 1.13 & 3.05 & \\
\hline 72 & Personal services & 1.36 & 2.39 & 13.22 & \\
\hline 73 & Business services & 19.41 & 41.68 & 118.21 & \\
\hline 75 & Automotive repair, services and parking & 11.87 & 35.92 & 161.59 & $\begin{array}{l}\text { A utomotive dealers and gasoline } \\
\text { service stations }\end{array}$ \\
\hline 76 & Miscellaneous repair services & 1.54 & 11.32 & 33.19 & Miscellaneous retail \\
\hline 78 & Motion pictures & 1.07 & 63.83 & 78.01 & Amusement and recreation services \\
\hline 79 & Amusement and recreation services & 1.07 & 63.83 & 78.01 & \\
\hline 80 & Health services & 2.38 & 3.02 & 4.38 & \\
\hline 81 & Legal services & 2.38 & 3.02 & 4.38 & Health services \\
\hline 82 & Educational services & 0.30 & 1.13 & 4.27 & \\
\hline 83 & Social services & 2.38 & 3.02 & 4.38 & \\
\hline 86 & Membership organizations & 0.30 & 1.13 & 4.27 & Educational services \\
\hline $\begin{array}{l}84,87 \\
, 89\end{array}$ & Other Services & 4.26 & 12.29 & 50.43 & \\
\hline 88 & Private households & 0.03 & 0.15 & 1.64 & \\
\hline & State G overnment & 5.05 & 8.36 & 19.84 & \\
\hline & Federal G overnment & 0.24 & 5.16 & 20.05 & \\
\hline \multicolumn{6}{|c|}{$\begin{array}{l}\text { Notes } \\
\text { D ata shown were converted from } 1992 \$ \text { Canadian to } \$ \text { US and adjusted for inflation as follows: } \\
\$ \text { Canadian to } \$ \text { US Conversion Factors } \\
19920.83 \text { Used for Industrial, Residential and Commercial } \\
19960.73 \text { Used for G overnment, Institution and Office }\end{array}$} \\
\hline
\end{tabular}


Table A-5. GDP or Industry Output by SIC Code (\$Billions of Chained 1996 Dollars) ${ }^{(1)}$

\begin{tabular}{|c|c|c|c|c|c|}
\hline $\begin{array}{c}\text { SIC } \\
\text { Code }\end{array}$ & Description & $\begin{array}{l}1994 \\
\text { GDP }\end{array}$ & $\begin{array}{l}1995 \\
\text { GDP }\end{array}$ & Output & \begin{tabular}{|l|} 
Share of \\
Sector \\
Output (\%) \\
\end{tabular} \\
\hline 01 & Agriculture products - crops & & & 71.8 & 40.3 \\
\hline 02 & Agriculture production - livestock & & & 76.0 & 42.6 \\
\hline 07 & Agriculture service & & & 22.9 & 12.9 \\
\hline 08 & Forestry & & & 4.3 & 2.4 \\
\hline 09 & Fishing, hunting and trapping & & & 3.1 & 1.8 \\
\hline 10 & Metal mining & 5.7 & 5.5 & & \\
\hline 12 & Coal Mining & 9.6 & 10.1 & & \\
\hline 13 & $O$ il and $G$ as Extraction & 83.8 & 88.6 & & \\
\hline 14 & Mining and quarrying of nonmetallic minerals & 9.1 & 9.1 & & \\
\hline $15-17$ & Construction & 297.2 & 299.6 & & \\
\hline 20 & Food and Kindred Products & 112.6 & 133.3 & & \\
\hline 21 & Tobacco manufactures & 13.8 & 15.7 & & \\
\hline 22 & Textile mill products & 26.9 & 26.0 & & \\
\hline 23 & $\begin{array}{l}\text { Apparel and Other Finished Products Made from } \\
\text { Fabrics }\end{array}$ & 28.4 & 28.0 & & \\
\hline 24 & Wood Products & 38.9 & 41.6 & & \\
\hline 25 & Furniture and fixtures & 20.2 & 20.7 & & \\
\hline 26 & Paper and allied products & 61.3 & 52.2 & & \\
\hline 27 & Printing and publishing & 92.6 & 89.2 & & \\
\hline 28 & Chemicals and allied products & 145.5 & 148.0 & & \\
\hline 29 & Petroleum and coal products & 22.0 & 26.9 & & \\
\hline 30 & Rubber and Miscellaneous Plastic Products & 44.9 & 47.0 & & \\
\hline 31 & Leather and leather products & 5.1 & 5.3 & & \\
\hline 32 & Stone, clay, glass, and concrete products & 32.0 & 32.8 & & \\
\hline 33 & Primary metal industries & 50.5 & 49.6 & & \\
\hline 34 & Fabricated metal pro ducts & 86.4 & 90.8 & & \\
\hline 35 & Industrial machinery and equipment & 106.8 & 124.7 & & \\
\hline
\end{tabular}


Table A-5. GDP or Industry Output by SIC Code (\$Billions of Chained 1996 Dollars) ${ }^{(1}$ - continued

\begin{tabular}{|c|c|c|c|c|c|}
\hline 36 & Electrical and electronic equipment & 103.3 & 128.7 & & \\
\hline 37 & Transportation equipment & 151.3 & 152.6 & & \\
\hline 38 & Instruments and related products & 53.8 & 52.6 & & \\
\hline 39 & Miscellaneous manufacturing industries & 22.6 & 23.3 & & \\
\hline 40 & Railroad Transportation & 22.1 & 22.7 & & \\
\hline 41 & $\begin{array}{l}\text { Local and suburban transit and hwy passenger } \\
\text { transport }\end{array}$ & 12.8 & 13.2 & & \\
\hline 42 & Motor freight transportation and warehousing & 85.3 & 86.6 & & \\
\hline 44 & Water transportation & 11.3 & 11.3 & & \\
\hline 45 & Transportation by air & 59.6 & 62.9 & & \\
\hline 46 & Pipelines, except natural gas & 5.5 & 5.0 & & \\
\hline 47 & Transportation services & 22.1 & 23.4 & & \\
\hline 48 & Communications & 190.8 & 202.4 & & \\
\hline 49 & Electric, gas and sanitary services & 196.7 & 207.2 & & \\
\hline $50-51$ & Wholesale trade & 481.6 & 483.0 & & \\
\hline 52 & Building materials & & & 27.2 & 4.5 \\
\hline 53 & General merchandise & & & 60.6 & 10.0 \\
\hline 54 & Food stores & & & 83.8 & 13.9 \\
\hline 55 & Automotive dealers and gasoline service stations & & & 104.1 & 17.3 \\
\hline 56 & Apparel and accessory stores & & & 35.2 & 5.8 \\
\hline 57 & Home furniture, furnishings and equipment stores & & & 32.5 & 5.4 \\
\hline 58 & E ating and drinking places & & & 169.2 & 28.1 \\
\hline 59 & Miscellaneous retail & & & 90.5 & 15.0 \\
\hline 60 & Depository Institutions & 227.9 & 242.4 & & \\
\hline 61 & Nondepository credit institutions & 29.9 & 33.4 & & \\
\hline 62 & Security and commodity brokers, dealers and services & 75.9 & 76.5 & & \\
\hline 63 & Insurance carriers & 127.7 & 129.9 & & \\
\hline 64 & Insurance agents, brokers and service & 51.6 & 49.9 & & \\
\hline 65 & Real estate & 827.7 & 852.8 & & \\
\hline 67 & Holding and other investment offices & 8.5 & 9.9 & & \\
\hline 70 & Hotels, rooming houses, camps and other lodging & 58.3 & 62.7 & & \\
\hline 72 & Personal services & 47.8 & 48.1 & & \\
\hline
\end{tabular}

A-11 
Table A-5. GDP or Industry Output by SIC Code (\$Billions of Chained 1996 Dollars) ${ }^{(1}$ - continued

\begin{tabular}{|c|c|c|c|c|}
\hline 73 & Business services & 295.0 & 313.9 & \\
\hline 75 & Automotive repair, services and parking & 62.9 & 65.9 & \\
\hline 76 & Miscellaneous repair services & 21.4 & 22.4 & \\
\hline 78 & Motion pictures & 21.7 & 23.6 & \\
\hline 79 & Amusement and recreation services & 52.6 & 55.6 & \\
\hline 80 & Health services & 438.2 & 444.3 & \\
\hline 81 & Legal services & 101.6 & 105.1 & \\
\hline 82 & Educational services & 56.7 & 58.5 & \\
\hline 83 & Social services & 47.2 & 49.3 & \\
\hline 86 & Membership organizations & 50.8 & 49.0 & \\
\hline $84,87,89$ & Other Services & 192.1 & 199.9 & \\
\hline 88 & Private households & 11.8 & 12.2 & \\
\hline 91-97 & G overnment (2) & $1,016.0$ & 1,017.1 & \\
\hline Total & & $6,535.4$ & $6,742.0$ & \\
\hline
\end{tabular}

Commercial GD P Breakdown

Public Utilities, Comm. and Wholesale Trade

Retail Trade

Services

Government

Total
1994

\$Billions

869.1

617.2

$2,795.5$

$1,016.0$

$5,297.8$
1995

\$Billions

892.6

641.4

$2,893.1$

$1,017.1$

$5,444.2$ 
Table A-6. Electricity Consumption by Sector

\begin{tabular}{|l|l|l|}
\hline Sector & \multicolumn{2}{|l|}{$\begin{array}{l}\text { Energy Consumption by } \\
\text { Sector (Year 2000) }\end{array}$} \\
\hline & Q uadrillion BTU & Share (\%) \\
& & \\
\hline Industrial & 3.654 & 31.4 \\
\hline Commercial & 3.901 & 33.5 \\
\hline Residential & 4.072 & 35.0 \\
\hline Transportation & 0.018 & 0.2 \\
\hline Total & 11.65 & \\
\hline
\end{tabular}

Source: Energy Information Administration, September 2001 Monthly Energy Review 
A-14 


\subsection{Distribution}

No. of

Copies

\section{OFFSITE}

8 U.S. Department of Energy Distributed Energy Resources 1000 Independence Avenue SW Washington, DC 20024

ATTN: Pat Hoffman (4) Ron Fiskum (4)

3 U.S. Department of Energy Federal Energy Management Program 1000 Independence Avenue, SW Washington DC 20585

ATTN: B Shearer

J Glickman

S Herrera
No. of

Copies

\section{ONSITE}

1 DOE Richland Operations Office

D Biancosino

K8-50

25 Pacific Northwest National Laboratory

PJ Balducci (2) K6-05

WD Chvala K5-08

JG DeSteese (2) K5-20

BR Kinzey (4) BWO

TM Koehler K5-20

SA Parker K5-08

R Pawlowski K5-20

RG Pratt K5-16

JM Roop (2) K6-05

WF Sandusky K5-08

L Schienbein (2) K5-20

DL Smith K6-05

MR Weimar (2) K6-05

Project 30364 File (2) K5-20

Hanford Technical Library (2) P8-55 
